\title{
腹部大動脈瘤に対する人工血管置換術とステントグラフト内挿術に おける周術期の炎症・線溶凝固障害に関する血液学的比較分析
}

\author{
安藤 敬, 秋山 大地, 岡田 拓, 伊達 数馬, 後藤 博志, 竹田 誠
}

\begin{abstract}
要 旨：【目的】腹部大動脈瘤に対する人工血管置換術（O群）とステントグラフト内挿術（E群）の炎症・凝 固線溶系を血液学的比較分析した。【方法】紡錘状腹部大動脈瘤径 $45 \mathrm{~mm}$ 以上の $\mathrm{O}$ 群 16 例と $\mathrm{E}$ 群 6 例を比較。 【結果】両群間の最大短径に差なし。高齢でも短入院期間は $\mathrm{E}$ 群。術後合併症 $\mathrm{O}$ 群 1 例, $\mathrm{E}$ 群 1 例。 hsCRP 值 (ng/ $\mathrm{mL}$ ）は，術前有意差ないも，O群高值。TAT 值は E 群，PIC值はO群で高値。【結論】O 群は高炎症， E 群は高 線溶，凝固は両群とも収束した。(J Jpn Coll Angiol 2018; 58: 21-26)
\end{abstract}

Key words: abdominal aortic aneurysm, open vascular prosthesis replacement, endovascular aortic aneurysm repair, fibrinolysis coagulation disorder, inflammation

受付：2017年9月 19 日 受理：2018年1月 24 日 公開：2018年3月 10 日

\section{序言}

腹部大動脈瘤患者では, 健常人と比較しトロンビン・ アンチトロンビン複合体（TAT）やD-dimerが有意に高 值であり ${ }^{1)}$ ，大動脈瘤径と凝固抢よび線溶系の活性化 に相関関係があることが報告されている ${ }^{2)}$ 。安藤らは, $\mathrm{AAA}$ 瘤壁のプロテオミクス解析から, 瘤壁での凝固線 溶系の活性化と補体活性化による炎症が起こっているこ とを報告した ${ }^{3)}$ 。一方で，手術治療には，開腹による人 工血管置換術とステントグラフト内揮術がそれぞれ行わ れているが，周術期に打ける炎症や線溶凝固障害の観点 からの比較報告はまだ少なく, 当院の経験症例を検討し た。

\section{対象と方法}

2014 年 4 月 1 日から 2016 年 3 月 31 日までの 2 年間に当 院で経験した非破裂性腹部大動脈瘤70例に対して同意 が得られた 32 例で, 開腹による人工血管置換術が行わ れた 20 例とステントグラフト内挿術が行われた 12 例で あった。これらを対象とし後述する解析をまず行った が，標準偏差があまりにも大きかった（デー夕不揭載）。 対象症例の中には, 囊状瘤や総腸骨瘤に $45 \mathrm{~mm}$ 未満の腹

独立行政法人労働者健康安全機構横浜労災病院心臟血管外科 doi: 10.7133 jca.17-00030

\section{(c) BY-NC-ND}

部大動脈瘤併存症例が含まれているため, 腹部大動脈瘤 径を $45 \mathrm{~mm}$ 以上かつ形態が紡鍾状である症例のみを対象 とすることとした。結果として，比較対象となったのは $\mathrm{O}$ 群 16 例と E 群6例であった（なお，当院では，高齢で も原則開腹手術を基本治療方針とし，スクリーニング検 查で耐術困難な心肺機能と判断した症例と患者や紹介医 の希望がEVARである場合に，IFUに準じEVARを選択 している)。瘤最大短径, 瘤の長さ, 患者背景 (年齢, 性別，冠疾患や脳梗塞や糖尿病，開腹術既往の有無）, 周術期（術直前, 術直後, 術後1 病日目, 2 病日目, 7 病日目) の血液学的検査 (白血球数 (WBC), 血小板数 (Plt), AST, クレアチニン (Cre), AT, D-dimer, Fibrinogen, PIC, PT-INR, TAT, hsCRP 值), 手術時間, 大動脈遮断 時間, 術中出血量，ヘパリン総投与量，プロタミン総投 与量, 輸血投与量, 術後合併症の有無を比較した。統計 処理はSPSS（IBM, ver.22）で行い, $t$-検定， $\chi^{2}$ 検定を用 いて $p=0.05$ 未満を有意とした。

\section{結果}

$\mathrm{O}$ 群， E群間の内訳では, 瘤最大短径や長さは $\mathrm{O}$ 群に 大きい傾向にあったが，有意差は認めなかった。実際 の治療対象症例では $\mathrm{E}$ 群がより高齢の傾向だったが, 研 究対象例のみを比べるとO群のほうが高齢の傾向にあっ た。いずれも有意差は認めなかった。また，O群に開腹 術既往など併存症が多く，とくに腎不全症例（HD含め） はE群に認めなかった（Table 1)。術後合併症はO群1 
Table 1 Patients' characteristics

\begin{tabular}{lcc}
\hline & Group O & Group E \\
\hline Number & 16 & 6 \\
(Male/female) & $(14 / 2)$ & $(6 / 0)$ \\
Age (years old) & $59 \sim 83$ & $59 \sim 90$ \\
& $(73.1 \pm 6.5)$ & $(71.6 \pm 11.8)$ \\
Maximum diameter (mm) & $45 \sim 80$ & $45 \sim 57$ \\
& $(53.6 \pm 8.5)$ & $(50.6 \pm 3.9)$ \\
Length (mm) & $70 \sim 119$ & $42 \sim 102$ \\
& $(90.1 \pm 16.1)$ & $(70.6 \pm 22.3)$ \\
Cerebral infarction & 3 & 1 \\
Coronary artery disease & 7 & 3 \\
Diabetes & 3 & 3 \\
Chronic renal failure & 4 & 0 \\
(including HD) & $(2)$ & 1 \\
Past Abdominal operation & 5 & \\
\hline
\end{tabular}

Table 2 Postoperative profiles

\begin{tabular}{lccc}
\hline & Group O & Group E & $p$ value \\
\hline Heparin & $5 \sim 11$ & $5 \sim 11$ & $p<0.05$ \\
$(\mathrm{~mL})$ & $(7.1 \pm 1.5)$ & $(6 \pm 2.4)$ & \\
Protamine & $5 \sim 13$ & 0 & $p<0.05$ \\
$(\mathrm{~mL})$ & $(7.7 \pm 2)$. & $(0 \pm 0)$ & \\
Blood transfusion & $0 \sim 4530$ & $0 \sim 840$ & $p<0.05$ \\
(mL) & $(842.5 \pm 1486)$ & $(140 \pm 342)$ & \\
Operation time & $241 \sim 644$ & $123 \sim 612$ & $p<0.01$ \\
(min) & $(380 \pm 133)$ & $(226 \pm 190)$ & \\
Complication & 1 例 & 1 例 & \\
& $($ イレウス) & $($ 下肢閉塞 $)$ & \\
Hospital stay & $8 \sim 27$ & $7 \sim 10$ & $p<0.01$ \\
(postoperative days) & $(15.5 \pm 4.6)$ & $(7.6 \pm 1.2)$ & \\
\hline
\end{tabular}

例（術後イレウス），E群1例（下肢閉塞）であった。へ パリン総投与量，プロタミン総投与量，他科血輸血量 には，すべて有意差を認め，手術時間も入院期間も $\mathrm{E}$ 群 が明らかに短かった。O群では，大動脈遮断前にへパリ ンを $1 \mathrm{~mL} / \mathrm{kg}$ 投与し ACT 200 秒以上で遮断し， 30 分ごと

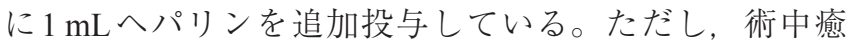
着剥離時の静脈損傷や腰動脈などからの出血が多かった 場合は，適宜 ACT 值を測定し投与しない場合もあった (Table 2)。なお，使用デバイスは，O群は16例すべて Triplex（テルモ社），E群は5例ENDURANT（Medtronic 社)，1例 Powerlink（Endologix 社）が用いられた。

血液学的分析では, まず $\mathrm{O}, \mathrm{E}$ 群間の炎症反応の推移 をみると, $\mathrm{WBC}$ 数值 $\left(/ \mathrm{mm}^{3}\right)$ では, $\mathrm{O}$ 群は術直後から
POD1まで急上昇し POD2 以降低下し, E群は一日遅れ POD2に最高值に達した。POD1, POD2で有意差を認め た。しかし，O，E群間の hsCRP值 $(\mathrm{ng} / \mathrm{mL})$ 比較では, 術前からE群がやや高いが有意差認めず, 両群とも最 高值をPOD2に示し有意差も認めた。POD7時には両群 とも術前の8倍程度に急速に低下したが, 測定值には有 意差は認めなかった。AT值を比較すると, O群で術直 後に急激に低下し, POD7にはほぼ術前值に戻った。 群では大きな変動なく，すべての継続時点で $\mathrm{O}$ 群より 高值を維持したが，有意差は認めなかった（以上 3 項目 はFig. 1参照)。次に, 凝固マーカーとしてTAT值を比 較すると, 術前は $\mathrm{O}$ 群が高值だったが, 術直後の時点 ではE群の異常高值が目立ち逆転した。そして両群とも POD1に急速低下しPOD7には収束した。各時点での計 測値は術前值のみ有意差を認めた。さらに, 血小板の值 やFibrinogenの值は両群とも同様な変化を示し, 有意差 は認めなかった（以上 3 項目はFig. 2 参照）。最後に, 線 溶マーカーとしてPIC值を比較すると両群では異なっ た動態を示した。E群では術直後から異常高值が目立 ち, POD1の時点で有意差を認めた。O群では, 術前值 こそ高值だが, 術直後よりPOD2まで低下し, POD7に 再上昇して術前值に戻った。また，抗凝固マーカーとし てPT-INR 值を比較したが, 両群とも同様な変化を示し, 有意差は認めなかった。さらに, 線溶凝固の両系統を反 映するが二次線溶のマーカーともされるD-dimer值を比 較するとO群の変化はPOD7に異常高值を呈した。E群 は二峰性変動を示した。有意差を認めたのはPOD1の時 点のみだった（以上 3 項目はFig. 3参照）。

\section{考察}

手術侵襲とは高度な炎症であり，とくに大動脈手術で は，血管刺激が補体や白血球や血小板を活性化し，まず 血栓傾向を呈する。つまり, 凝固活性がまず出現し, 過 剩血栓傾向となり, やがて線溶活性となることが推測 できる。今回, 炎症マーカーにhsCRPを, 凝固と線溶 マーカーにTATとPICを用いた。hsCRPは, 心筋梗塞発 生リスクと有意な相関を認める炎症マーカーとして多く 報告 ${ }^{4)}$ されているが, 腹部大動脈瘤発生に関する研究 5$)$ もありより鋭敏な炎症を反映することを期待したから である。TAT, PICの両者は, 凝固を反映するトロンビン や線溶を反映するプラスミンの血中半減期が極めて短 く直接測定できないため, 以前から多く用いられてお り, 当研究にも解析しやすいマーカーと判断したからで ある。すなわち, 凝固系では, トロンビンと阻止因子ア 

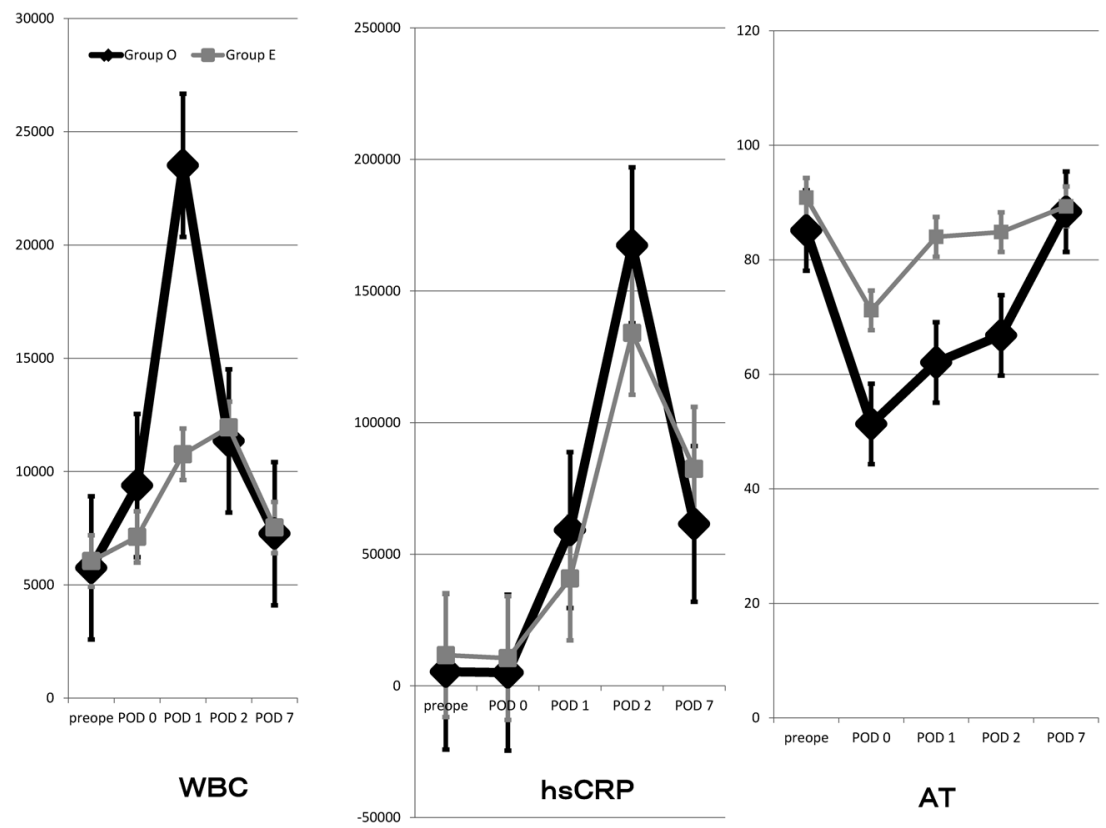

Figure 1 Perioperative white blood cell, high sensitive C-reactive protein and AT in Group O and Group E, AT: antithrombin, POD: postoperative day

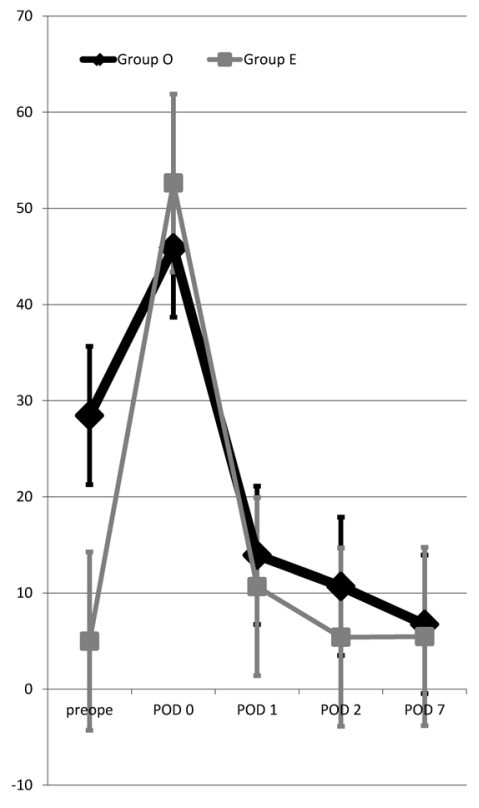

TAT
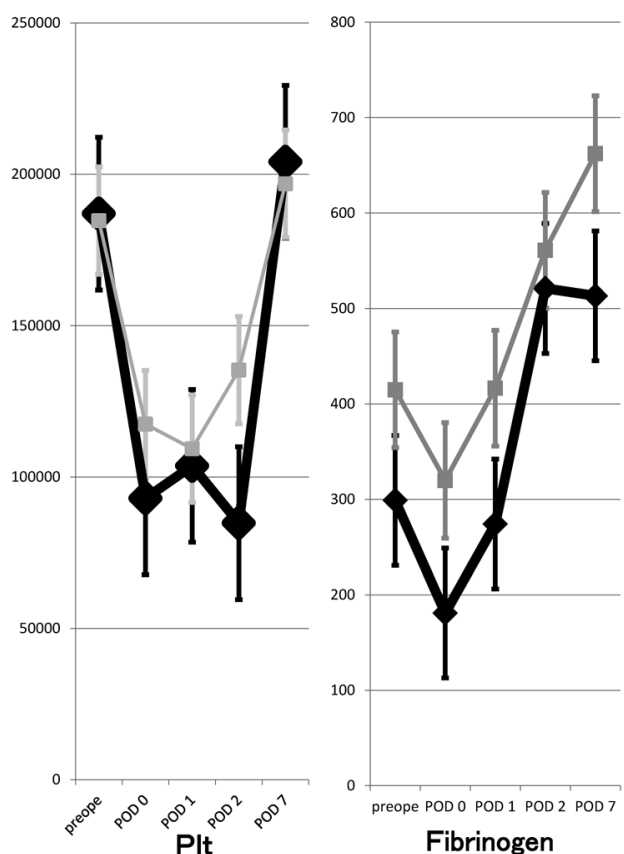

Figure 2 Perioperative TAT, Plt and Fibrinogen in Group O and Group E, TAT: thrombin-antithrombin complex, Plt: platelet, POD: postoperative day

ンチトロンビンが1対 1 結合した複合体である TAT は数 分の半減期であり，測定も可能で高值ならトロンビン産 生量が多いと判断できる。しかし, TAT は採血上駆血操 作だけでも上昇するとされ，可溶性フィブリンモノマー 複合体がより鋭敏とする報告も多くなっており ${ }^{6}$ ，当研 究でも測定すべき項目であっただろう。また，線溶系で

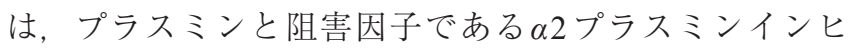
ビターが，1対 1 結合した複合体であるプラスミン $-\alpha 2$ プ
ラスミンインヒビター複合体 (PIC) も測定可能な半減 期であり，高值ならプラスミン産生量が多いと判断でき る。ただし，正常值を示す病態でも肝予備能低下により 低下し，著減する病態でも高度の炎症反応によりあまり 低下しないことも知られている。

まず，炎症反応だが，一般に使用されるCRP值との 傾向は同じものの (デー夕不掲載), より両群の差異が 把握するのに役立った。そこで, 抗炎症作用が研究さ 


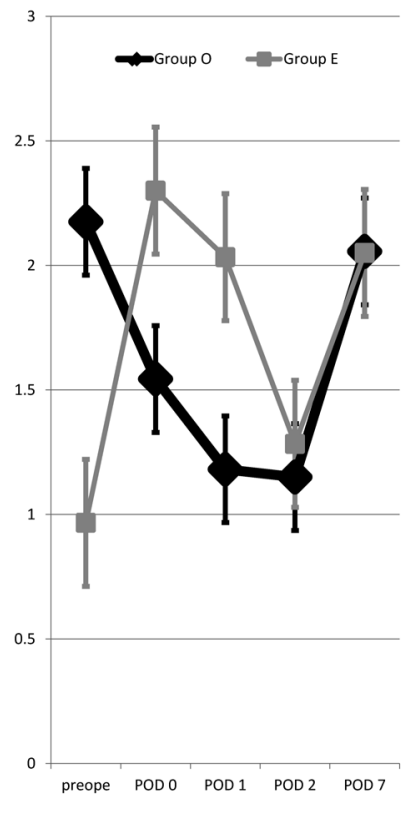

PIC

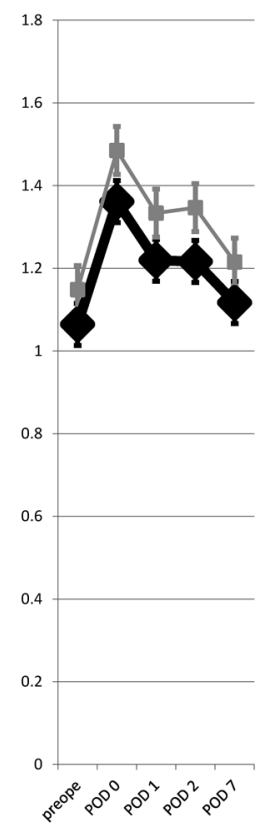

PT-INR

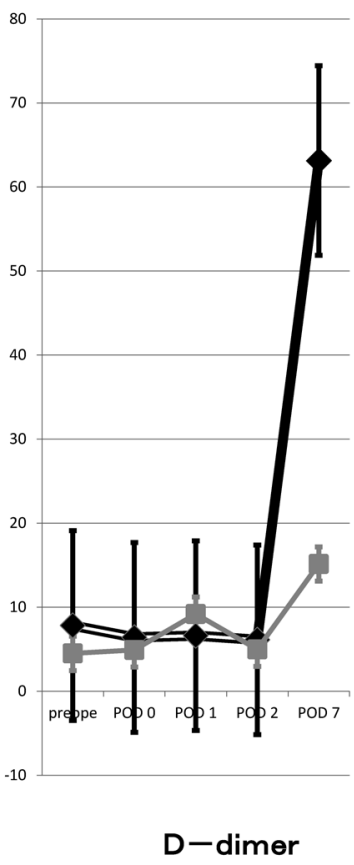

Figure 3 Perioperative PIC, PT-INR and D-dimer in Group O and Group E, PIC: plasmin- $\alpha 2$ plasmin inhibitor complex, PT-INR: prothrombin time-international normalized ratio, POD: postoperative day

れているATと比較してみた。ATは，好中球のサイトカ イン抑制作用の他に, トロンビンや活性化血液凝固第 X 因子を阻害することによって Protease-activated receptors を介した抗炎症作用があると報告されている7)。実際, 人工心肺バイパス手術後の ICU入室時の AT 值が多変量 解析の結果, 術後の神経障害, 血栓症, ICU入室期間, ICUの 8 日以上の滞在において有意に関連し, ICUの 8 日以上滞在のCut off值はAT值 58\%であることが報告さ れている ${ }^{8)}$ 。今回の自験例では抗炎症効果を示唆する合 併症の有無で, AT值を検討した。O群の合併症症例は 術前 $86 \%$ が術直後, POD1, POD2の順に, 41, 47, 58 と低 下していた。ところが $\mathrm{E}$ 群の合併症症例を見ると，時系 列順に，96, 70, 81, 88であり，侵襲が小さい $\mathrm{E}$ 群ではAT 值も保たれ, 侵襲が大きいO 群では術直後に急速に低下 するも徐々に回復し, hsCRPとの連動は認めなかった。 $\mathrm{O}$ 群の瘤切除が $\mathrm{E}$ 群の瘤残存状況より寄与した点がある かに関しては, 術後の炎症反応縮小率が $\mathrm{O}$ 群に著明だっ た点が関与しているかもしれないが, 術直後の炎症反応 に差があるため，比較できない。いずれせよAT活性の 術後推移を発表した報告は非常に少なく，本研究の術後 推移も，貴重な報告と思われた。

次に, 線溶と凝固の各マーカーの動向から, O 群で術 直後からPOD1まで凝固活性が認められ, POD2までは 認められなかった線溶活性がPOD7に認められた傾向は 予想通りの結果であった。ところが，E群では過凝固は 術直後のみ認められ, 術直後より線溶活性立進が出現す
るも，POD2には低下し，再度POD7に上昇する二峰性 となった。これは, 生体反応としては, 予想外のことで あった。E群の治療内容からも, 瘤内の急激な血栓形成 による凝固立進が一定期間続き, やがて二次線溶立進と なる予想だったが, 非常に短時間で二次線溶に転じてい る可能性を示唆された。とくに，E群でPOD1の時点で 有意差を認めた点は, 凝固も線溶も上昇するいわゆる線 溶元進型DICの病態を呈しており, 大動脈遮断を行い血 流途絶されたうえでの $\mathrm{O}$ 群と比べ，血流がある中での血 管内皮への直接刺激や人工血管素材でない金属ステント 露出などより固い異物との直接接触などが瞬時に起きた ための生体反応を観察しているかもしれない。腹部大 動脈瘤治療方法による比較論文 ${ }^{9)}$ や E 群に特徵的な合併 症であるエンドリーク研究の中では, FDPが有用なマー カーとされる報告もあったが10), 本研究では, フィブ リノゲン分解産物（一次線溶）とフィブリン分解産物 (二次線溶) の総和であるFDPではなく, フィブリン分 解産物 (二次線溶) の最小単位とされるD-dimerを測定 した。PICと同時に測定することで二次線溶をより反映 できると考えたからである。ただし，本研究でD-dimer 值がO群のPOD7で高值を示すも, E 群と有意差はない とされた背景には，非常に高い值を示した症例が含まれ ていたことが影響したのだろう。O群に術前から非常に 高い症例が2例（ともに慢性腎不全症例）あり，術前の

D-dimer值 $(\mu \mathrm{g} / \mathrm{mL})$ は20.52 と 35 であった。

本研究で, 二次線溶立進がどこまで継続するのかが結 
果が得られなかったのは, 当研究の観察期間が周術期の 急性期のみであり，測定值に反映されなかったことが考 えられる。そこで，実臨床で頻用される，日本救急医学 会急性期 DIC 診断基準（急性期基準） ${ }^{11}$ ) 参考に，各 時点でのDIC スコアも算出したが，個々の凝固マーカー や線溶マーカーとは連動する傾向は認めなかった（デー 夕不掲載)。複数の要因が重なっており, 過凝固から線 溶という直線的な変化を呈さないためと思われた。な お，O群は積極的に分枝再建をしたり，腎動脈遮断を要 したり，経験の少ない執刀医などを反映し，手術時間も 標準時間より長い印象がある。この結果，同種血輸血の 機会も多く, 自己血回収装置からの返血も, 凝固線溶系 変動に影響を与えるだろう。さらに，使用デバイスの血 液接触面積の観点からは，E群は内腔のみならず外腔も 血液と接触して招り，O群との比較検討は血液学的分析 だけでは，非常に困難であった。ただし，E群では，エ ンドリーク予測因子と治療方針の検討が課題になって おり ${ }^{10,12-14)}$ ，凝固系光進が遠隔期に瘤径を縮小させるの か，線溶系元進が遠隔期のエンドリークを示唆するのか など今後もさまざまな血液学的マーカーを追跡する必要 はあり，本研究の術後推移も，貴重な報告と思われた。

\section{結 論}

$\mathrm{O}$ 群は炎症も凝固線溶障害も周術期には激しく変動 し，手術侵襲の大きさを反映していた。E群は高リスク 症例が増加したが，合併症出現も低く，短期入院での治 療が行われた。さらに，術直後に過凝固が見られたが， 周術期中に是正された。二次線溶の持続時間は不明だっ た。今後も，遠隔期まで含めたフォローが望まれた。

謝辞

本研究は独立行政法人労働者健康安全機構『病院機能 向上のための研究活動支援』による助成金を得た。

\section{利益相反}

著者全員に申告すべき利益相反はない。

\section{付 記}

第 45 回日本血管外科学会総会 ( 2017 年 4 月, 広島) にて 発表した。

当研究は, 患者からインフォームドコンセントが得ら れ，院内倫理審査委員会(IRB)の承認を得た。

\section{文献}

1) Yamazumi $K$, Ojiro $M$, Okumura $H$, et al: An activated state of blood coagulation and fibrinolysis in patients with abdominal aortic aneurysm. Am J Surg 1998; 175: 297-301

2) Wallinder J, Bergqvist D, Henriksson AE: Haemostatic markers in patients with abdominal aortic aneurysm and the impact of aneurysm size. Thromb Res 2009; 124: 423-426

3) Ando T, Nagai K, Chikada M, et al: Proteomic analyses of aortic wall in patients with abdominal aortic aneurysm. J Cardiovasc Surg (Torino) 2011; 52: 545-555

4) Ridker PM, Cushman M, Stampfer MJ, et al: Inflammation, aspirin, and the risk of cardiovascular disease in apparently healthy men. N Engl J Med 1997; 336: 973-979

5) Huang G, Wang A, Li X, et al: Change in high-sensitive Creactive protein during abdominal aortic aneurysm formation. J Hypertens 2009; 27: 1829-1837

6) 家子正裕, 高橋信彦： Soluble fibrin monomer complex soluble fibrin. Thrombosis Medicine 2011; 1: 177-181

7) Koster A, Chew D, Kuebler W, et al: High antithrombin III levels attenuate hemostatic activation and leukocyte activation during cardiopulmonary bypass. J Thorac Cardiovasc Surg 2003; 126: 906-907

8) Ranucci M, Frigiola A, Menicanti L, et al: Postoperative antithrombin levels and outcome in cardiac operations. Crit Care Med 2005; 33: 355-360

9) Davies RS, Abdelhamid M, Wall ML, et al: Coagulation, fibrinolysis, and platelet activation in patients undergoing open and endovascular repair of abdominal aortic aneurysm. J Vasc Surg 2011; 54: 865-878

10) Ikoma A, Nakai M, Sato $M$, et al: Changes in inflammatory, coagulopathic, and fibrinolytic responses after endovascular repair of an abdominal aortic aneurysm: relationship between fibrinogen degradation product levels and endoleaks. Jpn J Radiol 2014; 32: 347-355

11）丸藤 哲：急性期 DIC 診断基準の現状と今後の展開. Thrombosis Medicine 2015; 5: 39-43

12）善甫宜哉, 上田晃志郎，金田好和，他：EVAR術後遠 隔期エンドリークとその対策. J Jpn Coll Angiol 2013; 53: $171-177$

13) Chikazawa G, Hiraoka A, Totsugawa $T$, et al: Influencing factors for abdominal aortic aneurysm sac shrinkage and enlargement after EVAR: clinical reviews before introduction of preoperative coil embolization. Ann Vasc Dis 2014; 7: 280-285

14) Okada M, Handa N, Onohara T, et al; National Hospital Organization Network Study Group for Abdominal Aortic Aneurysm in Japan: Late sac behavior after endovascular aneurysm repair for abdominal aortic aneurysm. Ann Vasc Dis 2016; 9: 102-107 


\section{Hematological Analyses of Both Postoperative Inflammation and Fibrinolysis-coagulation Disorder in Patients with Abdominal Aortic Aneurysm between Vascular Prosthesis Replacement and Endovascular Repair}

Takashi Ando, Daichi Akiyama, Hiroshi Okada, Kazuma Date, Hiroshi Goto, and Makoto Takeda

Department of Cardiovascular Surgery, Yokohama Rosai Hospital, Kanagawa, Japan

Key words: abdominal aortic aneurysm, open vascular prosthesis replacement, endovascular aortic aneurysm repair, fibrinolysis coagulation disorder, inflammation

Objectives: We compared perioperative inflammation, fibrinolysis coagulation disorder in both vascular prosthesis replacement (Group O) and endovascular repair (Group E) in patients with abdominal aortic aneurysm. Methods: Thirty-two patients who an agreement was obtained were included in two years. We divided 32 patients into Group O (16 out of 20) and Group E (6 out of 12), adjusted both more than $45 \mathrm{~mm}$ diameter and fusiform. We compared that aneurysmal maximal diameter, patients' background, a perioperative hematologic test (blood count, biochemistry, fibrinolysis coagulation system, and high-sensitive Creactive protein level), and the presence or absence of postoperative complications. Results: The maximal diameter, comorbidities between both groups did not have the difference. Group E had a short length of stay. Postoperative complications were one Group O, one Group E. As for the hsCRP level (ng/mL), Group $\mathrm{O}$ was higher without a preoperative significant difference in 2POD.The TAT level was higher in Group E, and the PIC level was higher in Group O. Conclusions: Inflammation was higher in Group O, and it remains at 7POD. As for the fibrinolysis showed in Group E much more than Group O, the coagulation was converged in both groups at 7POD.

(J Jpn Coll Angiol 2018; 58: 21-26)

Online publication March 10, 2018 